\title{
PENGARUH INFLASI, RETURN ON ASSETS, RETURN ON EQUITY TERHADAP KEPUTUSAN INVESTASI PADA PERUSAHAAN AGRIBISNIS YANG TERDAFTAR DI BURSA EFEK INDONESIA
}

\author{
Ni Ketut Karyati \\ Program Studi Agribisnis, Fakultas Pertanian, Universitas Dwijendra Denpasar \\ Email : karyati_ketut@yahoo.com
}

I Ketut Sudama

Program Studi Manajemen, Fakultas Ekonomi dan Bisnis, Universitas Pendidikan Nasional Denpasar Email : iketutsudama31121958@gmail.com

\begin{abstract}
Abstrak
Bagi para investor yang ingin berinvestasi pada pasar modal, biasanya akan memerlukan informasi keuangan baik laporan keuangan maupun kinerja keuangan perusahaan yang disajikan secara akurat, relevan dan tentu dapat dipercaya sebagai dasar pengambilan keputusan.Tujuan penelitian ini adalah untuk mengetahui pengaruh antara variabel Inflasi $\left(\mathrm{X}_{1}\right)$ ROA $\left(\mathrm{X}_{2}\right)$, ROE $\left(\mathrm{X}_{3}\right)$ terhadap Keputusan Investasi Pada Perusahaan Agribisnis Yang Terdaftar Di BEI (Y). Penelitian ini menggunakan metode kuantitatif. Data yang digunakan adalah laporan keuangan Perusahaan Agribisnis yang terdaftar di Bursa Efek Indonesia Periode 2014-2018. Teknik pengumpulan data dengan studi dokumentasi. Teknik analisis data adalah teknik analisis kuantitatif dengan penggunakan program Statistical Product and Service Solutions (IMB SPSS Statistics 24). Berdasarkan hasil analisis data dan pembahasan dapat disimpulkan bahwa: (1) secara parsial tidak terdapat pengaruh antara variabel Inflasi $\left(\mathrm{X}_{1}\right)$ terhadap Keputusan Investasi Pada Perusahaan Agribisnis Yang Terdaftar Di BEI (Y). (2) $\operatorname{ROA}\left(\mathrm{X}_{2}\right)$ tidak memiliki pengaruh yang signifikan terhadap Keputusan Investasi Pada Perusahaan Agribisnis Yang Terdaftar Di BEI (Y). (3) terdapat pengaruh antara variabel $\operatorname{ROE}\left(\mathrm{X}_{3}\right)$ terhadap Keputusan Investasi Pada Perusahaan Agribisnis Yang Terdaftar Di BEI (Y). Berdasarkan Tabel ANOVA juga terlihat bahwa nilai koefesien $F$ adalah 2,356 dengan koefesien sig 0,089 yang berarti $>0,05$, maka dapat dikatakan bahwa $\mathrm{H}_{0}$ ditolak dan $\mathrm{H}_{\mathrm{a}}$ diterima. Jadi dari hasil regresi yang diperoleh tidak terdapat pengaruh yang signifikan dari variabel independen Inflasi, ROA dan ROE terhadap variabel dependen Keputusan Investasi Pada Perusahaan Agribisnis Yang Terdaftar Di BEI
\end{abstract}

Kata Kunci: Inflasi, Return On Assets, Return On Equity Keputusan Investasi

\begin{abstract}
Normally, investors who want to invest in the capital market need financial information, whether financial statements or financial performance of the company that are presented accurately, relevantly, and reliably, to help them make decisions. The aim of this study is to understand the influence of inflation $\left(\mathrm{X}_{1}\right) \mathrm{ROA}$ $\left(\mathrm{X}_{2}\right)$, ROE $\left(\mathrm{X}_{3}\right)$ variables on investment decision on agribusiness companies listed on the IDX (Y). This study used qualitative method. The data used are financial statements of agribusiness companies listed on the IDX in the period 2014-2018. Data collection was done by documentation technique. Data were analyzed using quantitative analysis techniques using the Statistical Product and Service Solutions (IMB SPSS Statistics 24) program. Based on the results of data analysis and discussion it can be concluded that: (1) partially there is no influence between the inflation variable (X1) on investment decisions in agribusiness companies listed on the IDX (Y). (2) ROA (X2) does not have a significant influence on investment decisions in agribusiness companies listed on the IDX (Y). (3) there is an influence between the ROE (X3) variable on investment decisions in agribusiness companies listed on the IDX (Y). Based on the ANOVA table, it can also be seen that the coefficient value $F$ is 2.356 with a coefficient sig 0.089 which means $>0.05$, it can be stated that $\mathrm{H} 0$ is rejected and $\mathrm{Ha}$ is accepted. Therefore, from the regression results obtained, no significant effect was found from the independent variables Inflation, ROA and ROE on the dependent variable of investment decisions in agribusiness companies listed on the IDX
\end{abstract}

Keywords: Inflation, Return on Assets, Return On Equity, Investment Decisions 


\section{PENDAhUluAN}

Sektor pertanian mempunyai peranan yang sangat penting dalam perekonomian Indonesia, baik itu pada pertumbuhan ekonomi, penerimaan devisa negara, pemenuhan kebutuhan pangan, maupun penyerapan tenaga kerja (Sedana and Rahmat, 2020; Sedana and Astawa, 2019). Sektor pertanian juga merupakan penyedia bahan baku penting bagi keperluan industri, khususnya industri pengolahan makanan dan minuman (agroindustri), sebagai pilar utama dalam menopang ketahanan pangan negara(Putu Sugiartawan, et all., 2013; Komin and Sedana, 2019; Sedana and Astawa, 2018). Masyarakat Indonesia lebih dari empat puluh persen menggantungkan hidupnya pada sektor pertanian baik secara langsung maupun tidak langsung. Sektor pertanian juga menjadi sektor primer bagi banyak sektor, karena tidak sedikit hasil yang diproduksi oleh sektor pertanian yang juga diperlukan oleh sektor lain (Siregar, 2017; Sedana and Astawa, 2017)

Bursa Efek Indonesia telah menciptakan kesempatan bagi perusahaan pertanianyang bergerak di bidang agribisnis untuk menjadi perusahaan go public. Kinerja saham agribisnis di bursa saham juga menunjukan pertumbuhan, sehingga kelayakan akan berinvestasi di sektor pertanian khususnya dalam bentuk saham akan berdampak kepada hasil investasi yang dihasilkan (Putu Sugiartawan, et all., 2013). Pasar modal merupakan salah satu penggerak perekonomian suatu negara serta representasi untuk menilai kondisi perusahaan-perusahaan disuatu negara. Bagi investor pasar modal adalah pilihan investasi yang sesuai dengan preferensi mereka. Informasi yang akurat sangat diperlukan oleh investor sebagai alat analisis untuk mengambil keputusan investasi. Kemampuan investor dalam meramalkan kondisi ekonomi makro di masa datang akan sangat berguna dalam pembuatan keputusan investasi. Oleh karena itu investor harus mempertimbangkan indikator ekonomi makro seperti fluktuasi tingkat bunga, inflasi, kurs rupiah, dan pertumbuhan PDB sebagai dasar dalam membuat keputusan investasinya (Ima,2016).

Inflasi sebagai salah satu indikator tersebut merupakan suatu kondisi dimana harga barang-barang pada umumnya menjadi lebih tinggi dari sebelumnya. Inflasi yang berkaitan dengan pasar modal adalah investasi yang berasal dari sektor moneter. Hal ini karena inflasi berkaitan langsung dengan tingkat suku bunga dipasar. Jika inflasi meningkat maka tingkat suku bunga juga akan meningkat (Darmadji dan Fakhruddin, 2006). inflasi merupakan kenaikan tingkat harga yang secara terus menerus, mempengaruhi individu, pengusaha, dan pemerintah (Mishkin, 2008).

Pasar modal sebagai salah satu alternatif bagi investor dalam menanamkan dananya, pasti mengharapkan keuntungan dari investasi yang dilakukannya dimasa yang akan datang. Keuntungan merupakan salah satu faktoryang memotivasi investor untuk melakukan investasi dengan risiko yang sangat besar atas investasi yang dilakukannya (Nurlia \& Juwari, 2019). Di sisi lain pasar modal juga memiliki peranan yang penting untuk menunjang perekonomian suatu negara. Indikator perekonomian suatu negara, selain diukur melalui pertumbuhan Gross Domestic Product (GDP) juga dapat diukur melalui kinerja indeks pasar modal negara tersebut (Siregar, 2017).

Transaksi dipasar modal Indonesia mengalami perkembangan yang pesat dari periode ke periode, terbukti dengan meningkatnya jumlah saham yang ditransisikan dan tingginya volume perdagangan saham. Investor memerlukan informasi yang relevan dan alat pengukuran kinerja yang tepat, sehingga investor dapat mengetahui perusahaan yang memiliki kinerja keuangan yang baik dan nilai perusahaan 
yang tinggi. Sehingga investor dapat menentukan pilihan investasi di pasar modal yang memiliki imbal positif. Salah satu alternatif yang dapat dipilih oleh investor adalah dengan membeli instrumen pasar modal berupa saham, obligasi, atau waran. Sebelum investor melalukan pembelian saham, terlebih dahulu investor akan melakukan analisis terhadap kinerja perusahaan yang bersangkutan. Beberapa alat analisis yang bisa digunakan yakni analisis teknikal dan analisis fundamental. Analisis teknikal dapat dilihat dari pergerakan atau tren harga saham tersebut, sedangkan analisis fundamental dapat dilihat dari analisis rasio keuangan (Nurlia \& Juwari, 2017).

Analisis rasio keuangan dihitung berdasarkan data dari laporan keuangan yang menggambarkan kondisi keuangan suatu perusahaan pada saat tertentu atau pada periode tertentu (Sofyan, 2011). Beberapa macam analisis ratio keuangan yang digunakan dalam mengukur kinerja keuangan perusahaan diantaranya adalah analisis rasio profitabilitas. Analisis rasio profitabilitas menunjukkan keberhasilan perusahaan didalam menghasilkan keuntungan (Sutrisno, 2008).Rasio profitabilitas merupakan suatu kemampuan perusahaan dalam menciptakan laba(Nurlia \& Juwari, 2019). Dari rasio profitabiliras dapat diketahui nilai Return On Assets (ROA) danReturn OnEquity(ROE) perusahaan tersebut.

Return on Asset menunjukkan kemampuan perusahaandengan menggunakan seluruh aktiva yang dimiliki untuk menghasilkan laba setelahpajak. Rasio ini penting bagi pihak manajemen untuk mengevaluasi efektivitas danefisiensi manajemen perusahaan dalam mengelola seluruh aktiva perusahaan. Semakinbesar Return on Asset, berarti semakin efisien penggunaan aktiva perusahaan dan sebaliknya (Sudana dalam Nurlia, 2018).

Return On Equity adalah rasio yang menunjukkan kemampuan perusahaan dalam mengelola modal dari pemegang saham untuk mendapatkan laba bersih (Lestari et all., 2007). ROE menunjukan kemampuan perusahaan untuk menghasilkan laba setelah pajak dengan menggunakan modal sendiri yang dimiliki perusahaan. Investor yang akan membeli saham akan tertarik dengan ukuran profitabilitas ini, atau bagian dari total profitabilitas yang bisa dialokasikan ke pemegang saham (Hanafi dan Halim, 2012).

JikaReturn On Equity perusahaan meningkat, maka harga saham mengalami kenaikan. Semakin tinggi Return On Equity berarti semakin baik kinerja perusahaan dalam mengelola modalnya untuk menghasilkan keutungan (Sudoni et all., 2019). Investor biasanya akan semakin tertarik untuk menanamkan modalnya, karena invenstor sangat memperhatikan kemampuan perusahaan untuk menghasilkan keuntungan. Penilaian profitabilitas sesuai dengan ketetapan Bank Indonesia pada Surat Edaran Bank Indonesia No. 13/24/DPNP menyatakan bahwa faktor profitabilitas diukur dengan rasio Return On Asset (ROA) danReturn On Equity (ROE) (Rusdin, 2006dalam Sudoni, et all., 2019). Rasio ini menjadi bahan analisis investor yang mendasarkan jumlah investasi yang akan ditanamkannya.

Tandelilin (2001) dalam penelitiannya menyatakan bahwa tingginya inflasi juga dapat mengakibatkan turunnya daya beli masyarakat sebagai akibat dari naiknya harga-harga barang maupun jasa secara umum. Hal ini berdampak buruk bagi perusahaan, karena perusahaan akan kesulitan memperoleh profitabilitas. Bila angka profitabilitas perusahaan rendah, maka investor cenderung untuk tidak menginvestasi dananya, dan permintaan saham perusahaan menurun, hal ini berdampak pada menurunnya harga saham dan return saham dari perusahaan tersebut (Sasongko dan Wulandari, 2006). Penelitian Febi et all., (2017) bahwa secara simultan Return On Asset(ROA), Earning Per Share (EPS), 
Deviden Per Share (DPS), Debt To Assets Ratio (DAR), dan Current Ratio (CR) berpengaruh signifikan terhadap keputusan investasi pemegang saham dan secara parsial hanya ROA yang berpengaruh signifikan terhadap keputusan investasi pemegang saham.

Penelitian lain yang dilakukan oleh Gunawan dan Jati (2013) menyatakan bahwa terdapat pengaruh yang signifikan secara simultan antara variabel Net Profit Margin (NPM), Return On Asset(ROA), Return On Equity (ROE), Earning Per Share (EPS), terhadap return saham. Secara parsial tidak ada pengaruh yang signifikan variabel NPM, ROA dan ROE terhadap return saham. Dan ada pengaruh yang signifikan secara parsial variabel EPS dan Price Earning Ratio (PER) terhadap return saham, sehingga hal ini berpengaruh terhadap keputusannya dalam berinvestasi pada bursa saham. Hal inilah yang menarik peneliti untuk mengkaji penelitian "Pengaruh Inflasi, Return On Assets, Return On Equity Terhadap Keputusan Investasi pada Perusahaan Agribisnis Yang Terdaftar di Bursa Efek Indonesia"

\section{METODE}

Penelitian ini menggunakan metode kuantitatif. Populasi yang digunakan pada penelitian ini yaitu perusahaan agribisnis yang terdaftar pada Bursa Efek Indonesia periode 2014-2018. Dalam penelitian ini digunakan teknik purposive sampling dengan kriteria, perusahaan agribisnis yang terdaftar di Bursa Efek Indonesia periode 2014-2018 masih tetap menerbitkan laporan keuangan yang telah diaudit. Populasi dan sampel (sasaran penelitian) penelitian ini adalah perusahaan agribisnis yang terdaftar di Bursa Efek Indonesia periode 2014-2018 berjumlah 10 perusahaan. Teknik pengumpulan data dengan studi dokumentasi. Teknik analisis data adalah teknik analisis kuantitatif yakni dengan penggunakan program Statistical Product and Service Solutions (IMB SPSS Statistics 24).

\section{HASIL DAN PEMBAHASAN}

\subsection{Hasil Analisis Data}

a. Uji Asumsi Klasik

Pada penelitian ini uji asumsi klasik dilakukan melalui beberapa uji diantaranya adalah uji normalitas, uji multikolinearitas, autokorelasi dan heteroskedastisitas dengan menggunakan program Statistical Product and Service Solutions (IMB SPSS Statistics 24).

\section{1) Uji Normalitas}

Sebagaimana pada penelitian-penelitian yang dilakukan sebelumnya bahwa penggunaan uji normalitas bertujuan untuk menguji apakah dalam model regresi, variabel pengganggu atau residual memiliki distribusi normal. Uji t dan $\mathrm{f}$ mengasumsikan bahwa nilai residual mengikuti distribusi normal. Uji statistik yang dapat digunakan untuk menguji normalitas residual adalah uji statistik non-parametrik Kolmogorov-Smirnov (K-S). Model uji regresi dinyatakan memenuhi asumsi normalitas apabila hasil uji Kolmogorov-Smirnov (K-S) memiliki nilai Asymp.sig lebih besar dari 0,05. Adapun hasil analisis uji normalitas pada penelitian ini dapat ditunjukan pada Tabel berikut. 
Tabel 3.1

\section{Hasil Uji Normalitas}

\begin{tabular}{llr}
\multicolumn{2}{c}{ One-Sample Kolmogorov-Smirnov Test } \\
$\begin{array}{llr}\text { Unstandardized } \\
\text { Residual }\end{array}$ \\
\hline $\mathrm{N}$ & Mean & 39 \\
\cline { 2 - 3 } Normal Parameters ${ }^{\mathrm{a}, \mathrm{b}}$ & Std. Deviation & .0000000 \\
\hline Most Extreme Differences & Absolute & .13 .62387847 \\
\cline { 2 - 3 } & Positive & .109 \\
\cline { 2 - 3 } & Negative \\
\hline Test Statistic & .098 \\
\hline Asymp. Sig. (2-tailed) & .109 \\
\hline a. Test distribution is Normal. & $.200^{c, d}$ \\
\hline $\begin{array}{l}\text { b. Calculated from data. } \\
\text { c. Lilliefors Significance Correction. } \\
\text { d. This is a lower bound of the true significance. }\end{array}$
\end{tabular}

Berdasarkan hasil uji normalitas pada Tabel tersebut di atas, menunjukkan angka Asymp.sig adalah sebesar $0,200>0,05$ sehingga uji regresi dianggap memenuhi asumsi normalitas.

2) Uji Multikolineritas

Dalam penelitian ini uji multikolinearitas dimaksudkan adalah untuk menguji hubungan antar variabel. Uji multikolinearitas dilakukan dengan tujuan mengetahui hubungan antar variabel sehingga hasil yang didapat dari analisa hipotesis menjadi akurat. Adapun hasil uji multikolinearitas dapat ditunjukkan pada Tabel berikut.

Tabel 3.2

Hasil Uji Multikolineritas

\section{Coefficients $^{a}$}

\begin{tabular}{llr|r} 
& & \multicolumn{2}{c}{ Collinearity Statistics } \\
Model & & Tolerance & \multicolumn{1}{c}{ VIF } \\
\hline \multirow{2}{*}{1} & Inflasi_x1 & .881 & 1.136 \\
\cline { 2 - 4 } & ROA_x2 & .286 & 3.499 \\
\cline { 2 - 4 } & ROE_x3 & .307 & 3.260 \\
\hline
\end{tabular}

a. Dependent Variable:

Keputusan_Investasi_Publik_y

Berdasarkan pada Tabel Coefficients tersebut di atas, terlihat bahwa nilai tolerance Inflasi adalah $0,881>0,10$, ROA 0,286 > 0,10 dan ROE 0,307 > 0,10 sedangkan VIF dari Inflasi adalah 1,136 < 10, ROA $3.499<10$ dan ROE $3.260<10$ sehingga dari hasil uji multikolinearitas ini maka dapat dikatakan bahwa variabel terbebas dari masalah multikolineritas.

3) Uji Hesteroskedastisitas

Penelitian ini juga menggunakan uji hesteroskedastisitas dengan tujuanuntuk mengetahui adanya penyimpangan dari syarat-syarat asumsi klasik pada regresi linear, di mana dalam model regresi harus dipenuhi syarat tidak adanya heteroskedastisitas. 
Tabel 3.3

Hasil Uji Hesteroskedastisitas

\begin{tabular}{|c|c|c|c|c|c|c|}
\hline & & & Coefficients & & & \\
\hline & & & & Standardized & & \\
\hline & & Unstandardize & Coefficients & Coefficients & & \\
\hline Mode & & $\mathrm{B}$ & Std. Error & Beta & $t$ & Sig. \\
\hline 1 & (Constant) & $7.561 \mathrm{E}-15$ & 16.089 & & .000 & 1.000 \\
\hline & Inflasi_x1 & .000 & 5.245 & .000 & .000 & 1.000 \\
\hline & ROA_x2 & .000 & 1.025 & .000 & .000 & 1.000 \\
\hline & ROE $\times 3$ & .000 & .419 & .000 & .000 & 1.000 \\
\hline
\end{tabular}

a. Dependent Variable: abresid

Apabila nilai signifikansi (Sig.) yang dihasilkan ternyata $>0,05$ maka tidak terjadi gejala heteroskedastisitas.Dilihat dari Tabel diatas bahwa nilai Sig dari inflasi adalah 1,000, ROA adalah 1,000 dan ROE adalah 1,000 lebih besar dari 0,05 maka hasil dari uji heteroskedastisitas model ini dipastikan tidak adanya gejala hesteroskedastisitas dan layak menggunakan analisis regresi.

4) Uji Autokorelasi

Penggunaan uji autokorelasi dalam penelitian ini bertujuan untuk mengetahui ada atau tidaknya kolerasi antar anggota serangkaian data menurut ruang dan waktu.Uji autokorelasi ini dugunakan pada data yang memiliki rentang waktu seperti data yang digunakan pada penelitian ini yaitu data perusahaan di BEI dalam 5 periode yakni mulai tahun 2014-2018. Dalam pengujian akan digunakan metode dengan tingkat nila probabilitas $>0,05$ berarti tidak terjadi autokorelasi dan sebaliknya. Hasil dari uji autokorelasi bisa dilihat pada Tabel berikut.

Tabel 3.4

Hasil Uji Autokorelasi

\begin{tabular}{|c|c|c|c|c|c|}
\hline \multicolumn{6}{|c|}{ Model Summary } \\
\hline Model & $\mathrm{R}$ & R Square & $\begin{array}{l}\text { Adjusted R } \\
\text { Square } \\
\end{array}$ & $\begin{array}{c}\text { Std. Error of the } \\
\text { Estimate }\end{array}$ & Durbin-Watson \\
\hline 1 & $.410^{a}$ & .168 & .097 & 14.19576 & .620 \\
\hline
\end{tabular}

\section{a. Analisis Regresi Linier Berganda}

Sugiyono dan Agus Susanto (2015) menjelaskan bahwa analisis regresi ganda digunakan oleh peneliti, bila peneliti bermaksud meramalkan keadaan (naik turunnya) variabel dependen. Analisis regresi 
ganda akan dilakukan bila jumlah variabel independen minimal 2 variabel. Regresi linier berganda, memiliki beberapa variabel bebas (independen) yang mempengaruhi variabel terikat (dependen) yang jumlahnya hanya satu. Variabel bebas dalam penelitian ini adalah Inflasi $\left(\mathrm{X}_{1}\right)$, ROA $\left(\mathrm{X}_{2}\right)$ dan ROE $\left(\mathrm{X}_{3}\right)$ sedangkan variabel terikat dalam penelitian ini adalah Keputusan Investasi (Y).

Tabel 3.5

Hasil Analisis Linier Berganda

\begin{tabular}{|c|c|c|c|c|c|c|}
\hline \multicolumn{7}{|c|}{ Coefficients $^{a}$} \\
\hline \multirow[b]{3}{*}{ Model } & & \multirow{2}{*}{\multicolumn{2}{|c|}{ Unstandardized Coefficients }} & \multirow{3}{*}{$\begin{array}{c}\text { Standardized } \\
\text { Coefficients } \\
\text { Beta } \\
\end{array}$} & \multirow[b]{3}{*}{$t$} & \multirow[b]{3}{*}{ Sig. } \\
\hline & & & & & & \\
\hline & & $\mathrm{B}$ & Std. Error & & & \\
\hline \multirow[t]{4}{*}{1} & (Constant) & 31.029 & 16.089 & & 1.929 & .062 \\
\hline & Inflasi_x1 & -2.073 & 5.245 & -.065 & -.395 & .695 \\
\hline & ROA $\times 2$ & -1.896 & 1.025 & -.534 & -1.850 & .073 \\
\hline & ROE $\times 3$ & 1.049 & .419 & .697 & 2.505 & .017 \\
\hline
\end{tabular}

a. Dependent Variable: Keputusan_Investasi_Publik_y

Berdasarkan data pada Tabel 3.5 diatas diperoleh t-hitung untuk variabel inflasi sebesar -0,395 dengan nilai signifikan 0,695 > 0,05 sehingga dapat dikatakan bahwa inflasi tidak berpengaruh signifikan terhadap keputusan investasi.

Nilai t-hitung untuk variabel ROA sebesar $-1,850$ dengan nilai signifikan 0,073 > 0,05 sehingga dapat dikatakan bahwa ROA tidak berpengaruh signifikan terhadap keputusan investasi.Nilai t-hitung untuk variabel ROE sebesar 2,505 dengan nilai signifikan 0,017 < 0,05 sehingga dapat dikatakan bahwa ROE memiliki pengaruh signifikan terhadap keputusan investasi.

\section{b. Uji Kelayakan Model}

1) Uji Koefisien Determinasi (R2)

Pada penelitian ini koefisien determinasi (R2) digunakan untuk mengukur kemampuan model dalam menerangkan variasi variabel terikat (Kuncoro, 2011). Pengukuran ini dilakukan dengan menggunakan program Stastitical Package for the Social Sciences (SPSS). Nilai koefisien determinasi adalah diantara nol dan satu. Nilai R2 yang kecil berarti kemampuan variabel-variabel independen dalam menjelaskan variasi variabel dependen sangat terbatas. Nilai yang mendekati satu berarti variabel-variabel independen memberikan hampir semua informasi yang dibutuhkan untuk memprediksi variasi variabel dependen (Kuncoro, 2011).Apabila bermaksud membandingkan beberapa persamaan regresi tentu tidaklah valid apabila sekedar membandingkan $R^{2}$, sehingga $R^{2}$ perlu disesuaikan berdasarkan jumlah variabel yang dilibatkan. Dalam penelitian ini, koefisien determinan (R2) yang digunakan adalah Adjusted R Square, karena penelitian ini menggunakan lebih dari dua variabel bebas. Koefisien determinasi digunakan untuk mengukur kemampuan variabel bebas yakni: Inflasi $\left(\mathrm{X}_{1}\right), \operatorname{ROA}\left(\mathrm{X}_{2}\right)$ dan $\operatorname{ROE}\left(\mathrm{X}_{3}\right)$ dalam menjelaskan variabel terikat yaitu Keputusan Investasi (Y). Hasil analisis koefisien determinasi, ditunjukkan pada Tabel berikut. 
Tabel 3.6

\section{Hasil Koefisien Determinasi}

\begin{tabular}{|c|c|c|c|c|}
\hline \multicolumn{5}{|c|}{ Model Summary } \\
\hline Model & $\mathrm{R}$ & R Square & $\begin{array}{c}\text { Adjusted R } \\
\text { Square } \\
\end{array}$ & $\begin{array}{c}\text { Std. Error of the } \\
\text { Estimate }\end{array}$ \\
\hline 1 & $.410^{\mathrm{a}}$ & .168 & .097 & 14.19576 \\
\hline
\end{tabular}

a. Predictors: (Constant), Inflasi_x1, ROA_x2, ROE_x3

b. Dependent Variable: Keputusan_Investasi_Publik_y

Hasil analisis seperti pada Tabel 3.6 tersebut diatas diketahui bahwa koefisien determinasi (R2) atau Adjusted $R$ Square sebesar 0,097, yang berarti bahwa 9,7\% keputusan investasi pada penelitian ini dipengaruhi oleh Inflasi, ROA, dan ROE sedangkan 91,3\% dipengaruhi oleh faktor lain. Yang dimaksud dengan 91,3\% oleh faktor lain merupakan faktor lain selain, Inflasi, ROA dan ROE.

2) Uji-f (secara simultan)

Penelitian ini menggunakan uji-f dengan tujuan untuk mengetahui pengaruh signifikan variabel independen $(\mathrm{X})$ secara simultan terhadap variabel dependen $(\mathrm{Y})$. Untuk uji signifikansi regresi ganda, pengambilan keputusan dengan menggunakan taraf signifikansi 5\%. Apabila tingkat signifikansi (Sig.) pada tabel annova lebih kecil daripada $\square=0,05$ maka model regresi yang diperoleh adalah signifikan dan layak digunakan.

Tabel 3.7

Hasil Uji F (Simultan)

\begin{tabular}{llr|r|r|r|r}
\multicolumn{7}{c}{ ANOVA $^{\mathrm{a}}$} \\
Model & Sum of Squares & df & Mean Square & \multicolumn{1}{c}{ F } & \multicolumn{1}{c}{ Sig. } \\
\hline 1 & Regression & 1424.425 & 3 & 474.808 & 2.356 & $.089^{\mathrm{b}}$ \\
\cline { 2 - 7 } & Residual & 7053.182 & 35 & 201.519 & & \\
\cline { 2 - 7 } & Total & 8477.607 & 38 & & & \\
\hline
\end{tabular}

a. Dependent Variable: Keputusan_Investasi_Publik_y

b. Predictors: (Constant), Inflasi_x1, ROA_x2, ROE_x3

PadaTabel ANOVA di atas terlihat bahwa nilai koefesien F adalah 2,356 dengan koefesien sig 0,089 yang berarti > 0,05. maka dapat dikatakan bahwa $\mathrm{H}_{0}$ diterima dan $\mathrm{H}_{\mathrm{a}}$ ditolak, berarti bahwa hasil regresi yang diperoleh, tidak terdapat pengaruh yang signifikan dari variabel independen Inflasi, ROA, dan ROE terhadap variabel dependen keputusan investasi secara simultan.

3) Uji-t (secara parsial) 
Penggunaan uji-t pada penelitian ini adalah untuk menguji apakah masing-masing variabel bebas memiliki pengaruh signifikan terhadap variabel terikat. Taraf signifikansi yang digunakan adalah $5 \%$. Penelitian ini menggunakan uji satu sisi, apabila tingkat signifikansi t lebih besar dari $\alpha=0,05$, maka tidak terdapat pengaruh antara variabel bebas dengan variabel terikat. Sebaliknya apabila tingkat signifikansi t lebih kecil atau sama dengan $\alpha=0,05$, maka terdapat pengaruh antara variabel bebas dengan variabel terikat.

Tabel 3.8

Hasil Uji t (Parsial)

Coefficients $^{a}$

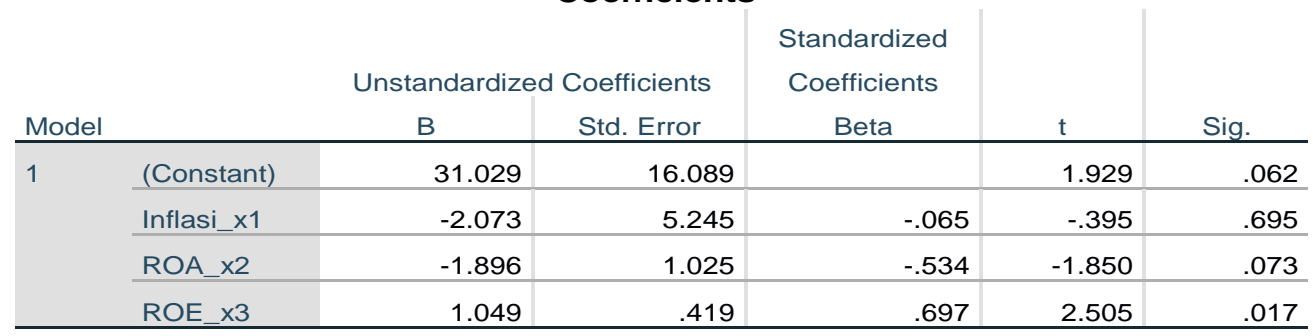

a. Dependent Variable: Keputusan_Investasi_Publik_y

a) Pengaruh secara parsial antara Inflasi $\left(\mathrm{X}_{1}\right)$ terhadap Keputusan Investasi Pada Perusahaan Agribisnis Yang Terdaftar di BEI (Y).

Berdasarkan hasil analisis sebagaimana yang ditunjukkan pada Tabel di atas menunjukkan nilai thitung Inflasi $\left(\mathrm{X}_{1}\right)$ adalah $-0,395$, dengan nilai signifikan 0,695 > 0,05, sehingga dapat dinyatakan bahwa tidak terdapat pengaruh yang signifikan antara variabel Inflasi $\left(\mathrm{X}_{1}\right)$ terhadap Keputusan Investasi pada Perusahaan Agribisnis Yang Terdaftar di BEI (Y).

b) Pengaruh secara parsial antara $\operatorname{ROA}\left(\mathrm{X}_{2}\right)$ terhadap Keputusan Investasi pada Perusahaan Agribisnis Yang Terdaftar Di BEI (Y).

Hasil analisis menunjukkan nilai t-hitung $\operatorname{ROA}\left(\mathrm{X}_{2}\right)$ adalah $-1,850$, dengan nilai signifikan 0,73>0,05, sehingga dapat dinyatakan bahwa tidak terdapat pengaruh yang signifikan antara variabel $\operatorname{ROA}\left(\mathrm{X}_{2}\right)$ terhadap Keputusan Investasi pada Perusahaan Agribisnis Yang Terdaftar di BEI (Y).

c) Pengaruh secara parsial antara $\operatorname{ROE}\left(\mathrm{X}_{3}\right)$ terhadap Keputusan Investasi pada Perusahaan Agribisnis Yang Terdaftar Di BEI (Y).

Hasil analisis menunjukkan nilai t-hitung $\operatorname{ROE}\left(\mathrm{X}_{3}\right)$ adalah 2.505, dengan nilai signifikan $0,17<0,05$, sehingga dapat dinyatakan bahwa terdapat pengaruh yang signifikan antara variabel $\operatorname{ROE}\left(\mathrm{X}_{3}\right)$ terhadap Keputusan Investasi pada Perusahaan Agribisnis Yang Terdaftar di BEI (Y).

\subsection{Pembahasan Pengaruh Inflasi, ROA, ROE terhadap Keputusan Investasi pada Perusahaan} Agribisnis Yang Terdaftar di BEI

Berdasarkan hasil pengolahan data, dimana hipotesis pertama yakni pengaruh Inflasi terhadap keputusan Investasi, menunjukkan hasil sig. $=0,695(\alpha>0.05)$ dan uji-t sebesar - 0,395. Hasil hipotesis pengaruh Inflasi terhadap Keputusan Investasi Pada Perusahaan Agribisnis Yang Terdaftar di BEI dapat diartikan bahwa Inflasi tidak memiliki pengaruh yang signifikan terhadap Keputusan Investasi pada 
Perusahaan Agribisnis Yang Terdaftar di BEI. Hal ini didukung dengan hasil uji koefisien determinasi yang menunjukan bahwa 91,3\% Keputusan Investasi pada Perusahaan Agribisnis Yang Terdaftar Di BEI dipengaruhi oleh faktor lain. Ini menunjukkan bahwa inflasi tidak menjadi perhatian oleh publik ketika mau berinvestasi pada perusahaan-perusahaan yang terdaftar di Bursa Efek Indonesia. Karena tingkat inflasi dapat berpengaruh positif maupun negatif tergantung derajat inflasi itu sendiri. Tetapi inflasi yang berlebihan dapat merugikan perekonomian secara keseluruhan yaitu dapatmembuat perusahan menghadapi resiko kebangkrutan. Sebagaimana pendapat Efni (2009) bahwa tingkat inflasi merupakan faktor yang harus dipertimbangkan dalam proses investasi. Inflasi merupakan indikator ekonomi yang menyebabkan kenaikan harga barang dan jasa dalam suatu periode. Adanya inflasi yang tinggi akan menyebabkan naiknya biaya produksi. Biaya produksi yang tinggi menyebabkan harga jual barang barang produksi naik. Hal ini akan menurunkan daya beli masyarakat. Menurunnya daya beli masyarakat mengakibatkan menurunnya penjualan perusahaan yang berimbas pada menurunnya keuntungan perusahaan.

Keuntungan perusahaan adalah salah satu faktor yang mempengaruhi keputusan investor untuk membeli saham. Jika keuntungan perusahaan kecil, investor cenderung enggan untuk menanamkan modalnya, sehingga harga saham mengalami penurunan akibat kurangnya permintaan terhadap saham tersebut. Berdasarkan hasil penelitian yang dilakukan peneliti saat ini dapat menguatkan hasil penelitian sebelumnya dari Permana dan Sularto (2008) yang menyatakan bahwa inflasi berpengaruh negatif terhadap harga saham. Serta Efni (2009) yang menyatakan bahwa terdapat pengaruh yang negatif signifikan dari tingkat inflasi terhadap harga saham perusahaan real estate dan property di Bursa Efek Indonesia (BEI), sehingga dapat diyakini akan mempengaruhi keputusan investor untuk perinvestasi di Bursa Efek Indonesia (BEI).

Hasil perhitungan uji-tstatistik secara parsial yang dilakukan oleh Bambang (2015) diperoleh bahwa inflasi tidak berpengaruh secara signifikan terhadapharga saham.Hasil tersebut sejalan dengan hasil penelitian terdahulu yang dilakukan oleh Permana (2009) yang hasilnya "Inflasi tidak berpengaruh secara signifikan terhadap harga saham". Hal tersebut berarti tidak menguatkan teori yang diungkapkan oleh Tandelilin (2010), peningkatan inflasi secara relatif merupakan sinyal negatif bagi pemodal di pasar modal. Artinya keputusan investasi yang dilakukan investor tidak terpengaruh oleh factor inflasi. Hal ini berarti, jika inflasi naik maka akan menurunkan harga saham dan sebaliknya jika inflasi menurun akan menaikkan harga saham. Hal ini disebabkan karena kondisi inflasi yang terjadi pada periode yang diteliti masih berada di angka yang tidak terlalu tinggi sehingga investor pun tetap berinvestasi dan membeli saham pada perusahaan yang terdaftar di Bursa Efek Indonesia.

Hipotesis kedua yaitu pengaruh ROA terhadap Keputusan Investasi Pada Perusahaan Agribisnis Yang Terdaftar Di BEI. Hasil penelitian menunjukkan bahwa nilai sig. yang diperoleh sebesar 0.073 ( $\alpha$ $>0.05$ ) dan uji-t sebesar -1,850.Ini berarti bahwa ROA tidak berpengaruh signifikan terhadap Keputusan Investasi pada Perusahaan Agribisnis Yang Terdaftar di BEI. Penelitian ini tidak sejalan dengan penelitian yang dilakukan oleh Handyansyah \& Dina (2016), dimana hasil penelitiannya menunjukkan bahwa ROA berpengaruh secara signifikan terhadap harga saham. ROA yang baik mencerminkan penggunaan dan pengelolaan aset perusahaan yang optimal sehingga akan menaikkan profitabilitas dan 
harga saham perusahaan. Ketika harga saham perusahaan naik, disini investor cenderung akan mengambil keputusan untuk menanamkan modalnya pada perusahaan-perusahaan yang memiliki tingkat profitabilitas yang tinggi dan tentunya bagi perusahaan yang memiliki harga saham yang bagus.

Sedangkan hipotesis ketiga yakni pengaruh ROE terhadap Keputusan Investasi Pada Perusahaan Agribisnis Yang Terdaftar di BEI, menunjukkan bahwa nilai sig. $=0.017(\alpha>0.05)$ dan uji-t sebesar 2,505. Ini berarti pengaruh ROE memiliki pengaruh yang signifikan terhadap Keputusan Investasi Publik Pada Perusahaan Agribisnis Yang Terdaftar di BEI. Nilai signifikansi tersebut lebih kecil dari tingkat alpha yang digunakan yaitu 5\% atau 0,05 . Semakin tinggi nilai ROE yang berhasil dicapai oleh perusahaan akan mencerminkan efektifitas laba dari modal perusahaan itu sendiri, hal ini menyebabkan investor semakin percaya untuk berinvestasi saham pada perusahaan yang memiliki nilai ROE yang tinggi. Hasil penelitian ini sejalan dengan penelitian yang dilakukan oleh Affinanda (2015) bahwa ROE memiliki pengaruh positif terhadap return saham. Penelitian dengan hasil yang sama juga dilakukan oleh Erwin (2013) dan Beny \& Mendari (2011) bahwa Return on Equity (ROE) memiliki pengaruh signifikan terhadap return saham. Jika return saham yang dicapai semakin baik, maka investor akan semakin cepat dalam mengambil keputusan untuk berinvestasi.

\section{PENUTUP}

\section{Simpulan}

Berdasarkan hasil analisis data dan pembahasan dapat disimpulkan bahwa: (1) secara parsial tidak terdapat pengaruh antara variabel Inflasi $\left(\mathrm{X}_{1}\right)$ terhadap Keputusan Investasi Pada Perusahaan Agribisnis Yang Terdaftar Di BEI (Y). (2) ROA $\left(\mathrm{X}_{2}\right)$ tidak memiliki pengaruh yang signifikan terhadap Keputusan Investasi Pada Perusahaan Agribisnis Yang Terdaftar Di BEI (Y). (3) terdapat pengaruh antara variabel $\operatorname{ROE}\left(\mathrm{X}_{3}\right)$ terhadap Keputusan Investasi Pada Perusahaan Agribisnis Yang Terdaftar Di BEI (Y).Berdasarkan Tabel ANOVA juga terlihat bahwa nilai koefesien F adalah 2,356 dengan koefesien sig 0,089 yang berarti > 0,05, maka dapat dikatakan bahwa $\mathrm{H}_{0}$ ditolak dan $\mathrm{H}_{\mathrm{a}}$ diterima. Jadi hasil regresi yang diperoleh tidak terdapat pengaruh yang signifikan dari variabel independen Inflasi, ROA dan ROE terhadap variabel dependen Keputusan Investasi Pada Perusahaan Agribisnis Yang Terdaftar Di BEI.

\section{Saran}

Berdasarkan hasil analisis data dan pembahasan maka penulis dapat menyarankan kepada masyarakat Indonesia yang ingin menanamkan modalnya atau berinvestasi melalui pembelian saham di Bursa Efek Indonesia, hendaknya melakukan kajian secara matang baik melalui data fundamental maupun data teknikal serta perlu juga memperhatikan faktor lainnya agar terhindar dari berbagai resiko kerugian yang cukup besar. Bagi Perusahaan agribisnis yang terdaftar di Bursa Efek Indonesia hendaknya melakukan efesiensi dalam penggunaan dananya, sehingga keuntungan perusahaan terus meningkatkan. Hal ini tentu akan dapat mempengaruhi keputusan investor untuk berinvestasi.

\section{DAFTAR PUSTAKA}

Bambang, Susanto. (2015). Pengaruh Inflasi, Bunga dan Nilai Tukar Terhadap Harga Saham (Studi Pada : Perusahaan Sektor Properti Dan Real Estate Tercatat BEI). Jurnal Aset (Akuntansi Riset), 7 (1), 2015, 29-38. 
Efni, Yulia. (2009). Pengaruh Suku Bunga Deposito, SBI, Kurs Dan Inflasi Terhadap Harga Saham Perusahaan Real Estate Dan Property Di BEI. Jurnal Ekonomi, Volume 17 no (01) Issn $0853 \pm 7593$. Pekanbaru : Universitas Riau.

Darmadji, Tjiptono dan Hendy M. Fakhruddin. (2006). Pasar Modal Di Indonesia Pendekatan Tanya Jawab Edisi 2. Jakarta : Salemba Empat.

Febi Ary Ramadhan, Brady Rikumahu, Tieka Trikartika Gustyana, (2017). Pengaruh Return On Assets, Earning Per Share, Dividend Per Share, Debt To Assets Ratio Dan Current Ratio Terhadap Keputusan Investasi Pemegang Saham (Studi Pada Perusahaan Telekomunikasi Yang Terdaftar Di Bursa Efek Indonesia Periode 2010-2015). e-Proceeding of Management : Vol.4, No.3 Desember 2017 Page 2148.

Gunawan, I Putu Ari dan Jati, I Ketut. (2013). Pengaruh Rasio Keuangan Terhadap Return Saham Dalam Pengambilan Keputusan Investasi Pada Saham Unggulan Yang Terdaftar Di Bursa Efek Indonesia. Fakultas Ekonomi Universitas Udayana (Unud), Bali, Indonesia

Hanafi, Mahduh dan Abdul Halim, (2012). Analisis Laporan Keuangan. UPP STIM YKPN, Yogyakarta.

Handyansyah, Muhammad Reza \& Dina Lestari. (2016). Pengaruh Return On Assets (ROA), Return On Equity (ROE), Net Profit Margin (NPM) dan Earning Per Share (EPS) Terhadap Harga Saham pada Perusahaan yang Terdaftar dalam Indeks LQ45 Bursa Efek Indonesia tahun 2012-2015.Jurusan Ilmu Administrasi Bisnis Fakultas Ilmu Sosial dan Ilmu Politik Universitas Diponegoro

Ima, Andriyani. (2016) Pengaruh Suku Bunga, Inflasi, Nilai Buku Terhadap Harga Saham Perusahaan Indeks LQ45 Yang Terdaftar Di Bursa Efek Indonesia (BEI). Jurnal Ilmiah Orasi Bisnis ${ }^{2}$ Volume 15 Bulan Mei 2016.

Komin, W. and G. Sedana. 2019. Sustainable Agricultural Tehcnologies on Rice Farming: Case of Subaks' in Bali Province, Indonesia. Journal of Sustainable Development Science 1 (1), 18-26.

Kuncoro, M. (2011). Metode kuantitatif. Yogyakarta: Sekolah Tinggi Ilmu.

Lestari, Annio Indah N, Muslich Lutfi dan Syahyunan (2007). Pengaruh Faktor Fundamental dan Teknikal TerhadapHarga Saham Properti yang Terdaftar di Bursa Efek Jakarta. Jurnal Ekonomi, Bisnis dan Akuntansi Vol. 2 No. 2, 87-109.

Mishkin, Frederic S. (2008). Ekonomi, Uang, Perbankan, dan Pasar Keuangan Buku 1.Terjemahan Lana Soelistianingsih dan Beta Yulianita G. Jakarta: Salemba Empat.

Nurlia, J. (2019). Pengaruh Return On Asset, Return On Equity, Earning Per Share Dan Current Ratio Terhadap Harga Saham Pada Perusahaan Sub Sektor Otomotif Dan Komponen Yang Terdaftar Di Bursa Efek Indonesia. Jurnal Geo Ekonomi ISSN-Elektronik (e): 2503-4790 | ISSN-Print (p): 2086$1117 \quad H$ Http://Jurnal.Fem.Uniba-Bpn.Ac.Id/Index.Php/Geoekonomi, 269. https://doi.org/10.24034/j25485024.y2011.v15.i2.2294.

Nurlia, \& Juwari. (2017). Pengaruh Return On Asset, Return On Equity, Earning Per Share Dan Current Ratio Terhadap Harga Saham Pada Perusahaan Sub Sektor Otomotif Dan Komponen Yang Terdaftar Di Bursa Efek Indonesia.Jurnal GeoEkonomi ISSN-Elektronik (e): 2503-4790 | ISSN-Print (p): 20861117 Http://Jurnal.Fem.Uniba-Bpn.Ac.Id/Index.Php/Geoekonomi, 1-10.

Permana, Yogi dan Lana Sularto. (2008). Analisis Pengaruh Fundamental Keuangan, Tingkat Bunga SBI Dan Tingkat Inflasi Terhadap Pergerakan Harga Saham. Jurnal Ekonomi Bisnis No. 2 Vol. 13 Hal $103 \pm 111$. Jakarta : Universitas Gunadarma.

Putu Sugiartawan, I W. Ramantha, K. B. S. (2013). Analisis Portofolio Saham Perusahaan Agribisnis di Bursa Efek Indonesia.Jurnal Manajemen Agribisnis, 1(1), 26260.

Sedana, G. and I N.D. Astawa. 2017. Revitalization of Farmers OrganizationFunctions Towards Agribusiness for Its Sustainability: Ideas for Traditional Irrigation Organizationin Bali Province, Indonesia. International Journal of Development Research 7 (11): 17020-17024.

Sedana, G. and I N.D. Astawa. 2018. Institutional Adjustment of Subak (Traditional Irrigation System) Orienting Business: Case of Cooperative of Subak Guama, Bali Province, Indonesia International Journal of Current Research Vol. 10, Issue 06:70418-70423. 
Sedana, G. and ND Astawa. 2019. Establishment of inclusive business on coffee production in Bali province: lesson from the coffee development project in Nusa Tenggara Timur province, Indonesia. Asian Journal of Agriculture and rural Development 9 (1), 111-122.

Sedana, G. and A. Rahmat. 2020. Alternatives Policies to Strengthen the Traditional Irrigation System for Suportting the Food Security Program: Case of the Subaks' System in Bali, Indonesia. International Journal of Advanced Science and Technology 29 (7s), 973-984.

Siregar, A. R. (2017). Analisis Pengaruh Rasio Profitabilitas Dan Rasio Solvabilitas Terhadap Pergerakan Harga Saham Sektor Pertanian Indonesia.Departemen Agribisnis Fakultas Ekonomi Dan Manajemen Institut Pertanian Bogor Bogor 2017, 53(9), 1689-1699. https://doi.org/10.1017/CBO9781107415324.004.

Sudoni, H., Suminartika, dan Ernha. (2019). Faktor-Faktor Yang Memengaruhi Harga Saham PT London Sumatra Indonesia Tbk. Agricore Volume 4 Nomor 2, Des 2019 Jurnal Agribisnis dan Sosial Ekonomi Pertanian UNPAD p-ISSN No. 2528-4576 / e-ISSN No. 2615-7411- 37.

Sugiyono, Agus Susanto, (2015). Cara Mudah Belajar SPSS \& LISREL Teori dan Aplikasi untuk Analisis Data Penelitian. Bandung: Alfabeta.

Sutrisno, Budi, dan Retno. (2008). Informasi Laba Perusahaan Hubungannya dengan Dinamika Perubahan Harga Saham Pada Perusahaan Manufaktur Di BEJ Tahun 2001. Jurnal Ekonomi.

Sofyan, Syafri Harahap. (2011). Analisis Kritis AtasLaporan Keuangan. Jakarta : Raja GrafindoPersada.

Tandelilin, Eduardus. (2001). Analisis Investasi dan Manajemen Portofolio, Edisi Pertama. BPFE Yogyakarta, Yogyakarta. 